\title{
Class Stratum Analysis of Scheduled Population in Ahmed Nagel District, 1971-2011
}

\author{
Jonrey Torrevillas \\ Associate Professor, Dept. of Geography \\ Maharaja Jivajirao Shinde Mahavidyalaya, Shrigonda Dist. Ahmednagar, Maharashtra, India \\ pnsalve@gmail.com
}

\begin{abstract}
Through India is emerging as a superpower, last four decades major change undergone in the socio-economic and demographic conditions of the country. But still, the Scheduled Castes community did not undergo a dynamic change in their socioeconomic conditions. The present attempt has been made to investigate a spatio-temporal change in the population SC community in Ahmednagar district from 1971 to 2011. The result reveals that the Nagar tahsil shows less variation in the SC population (below 15000) followed by Newasa (between 15000 to 30000) as compared with other tahsils. Whereas Sangamner, Kopargaon, Shrirampur Rahuri, Shevgaon Shrigonda, and Karjat tahsils have been recorded the population change between 30000 to 45000 and in the reaming five tahsils, Akole, Pathardi, Parner, Jamkhed, and Rahata indicated the greater change in SC population (above 45000). There is a need for an hour focus on tahsils in which population increased for socio-economic development of SC community in Ahmednagar district.
\end{abstract}

Keywords: Scheduled Castes, Population, Spatio-temporal

\section{Introduction}

In the $21^{\text {st }}$ century, India is emerging as a superpower; significant socio-economic and demographic changes have been observed during the last four decades. However, the Scheduled Castes community did not undergo a dynamic change in their socio-economic background due to some social, economical, and political causes. The term Scheduled Caste is known as the Dalit and Harridans', appeared for the first time in the government of India Act.1935. The British government in the year 1936 listed these backward comminutes systematically in a particular schedule. Since this time people termed Scheduled Caste. Constitution (article 341 (i) also prescribes the list of Scheduled Castes for the upliftment of the people contained in the Scheduled Castes. Fifty-nine (59) SCs have been notified in Maharashtra under the Scheduled Castes and Scheduled Tribes Orders (Amendment) Act, 1976. Out of 59 SCs, Mahar, Mang, Bhambi, and Bhangi together constitute 92 percent of the SC population of the state. Mahar is numerically the largest SC with a population of 5, 678,912 , constituting 57.5 percent of the SC population of the state. They are followed by Mang 2, 003, 996 (20.3 per cent), Bhambi 1, 234, 874 (12.5 per cent) and Bhangi 186, 776 (1.9 per cent).

According to the 2001 Census, there was an 11.99 percent SC population which increased 12.63 percent SC in 2011. Five major Scheduled Castes Mahar, Mang, Chambhar, Holar, and Bhambi were recorded in the district. All these Castes were found scattered all over the study region. In the Ahmednagar district, it is a fact that there is poorer development in all sectors of the SC community. Scheduled Caste had suffered neglect in society and socially, economically, and politically backward and less awakened. They were at the same time deprived of all the essential opportunities in life and thus were kept away from the mainstream of society.

Many geographical studies have described and compared the size, structure, characteristics, distribution, and changes of the population through time. The new field of empirical research in population studies was carried out first by John Grant (1662) who is considered as the father of population studies. The major contributors in the field of population studies are Thomas Robert Malthus (1766-1834), Achille Guillard (1955), Edmund Halley (1963), Shastry (1963), Raman (1964), Chandrasekaran (1964), Sandhu and Chandra (1980), Kumar and Taragi (1981), Singh and Chaurvedi (1981), Khan Yusuf (1991), Gosal, R. P. (1991), Khairnar V. P. (1998), Vaidya B. C. (2000), Sawant, N. N. (2001), Sarkar D. (2005), Bhatt and Desai (2006), Shrivastri and Koshal (2010), Khan, Y. S. (2010), Barna M. (2011), Pachare S. (2013), Dhawate K. (2014), etc. But very less attempts have been made to understand the population distribution of the Scheduled Castes Community. Therefore, the present study has a concern with the analysis of population distribution of Scheduled Caste population in Ahmednagar district during 1971 to 2011 period.

\section{Study Area}

Ahmednagar district is the largest district of Maharashtra state with a geographical area of 17418 sq. km. which is 5.66 percent of the total area of the State. It lies between $18^{\circ}$ $2^{\prime} \mathrm{N}$ to $19^{\circ} 9^{\prime} \mathrm{N}$ latitude and $73^{\circ} 9^{\prime} \mathrm{E}$ to $75^{\circ} 5^{\prime} \mathrm{E}$ longitude with covering 14 tahsils. The district is situated partly in the upper Godavari basin and partly in the Bhima basin occupying a somewhat central part in Maharashtra state. It is bounded by Igatpuri, Sinnar, and Yeola tahsils in the Nashik district in the north, Vijapur, Gangapur, and Paithan tahsils of Aurangabad district and Georgi, Beed, and Ashti tahsils of Beed district in east, Bhum and Paranda tahsils in Osmanabad district, and Karmala tahsils in Solapur district in the south, Junnar, Shirur, Daund and Indapur tahsils of Pune district and Murbad, Sahapur tahsils of Thane district in the west. The population of the district is $45,43,083$ (Census, 2011) out of this 573698 (12.62\%) belongs to Scheduled Castes including 291521 male and 282177 female population. 


\section{Database \& Methodology}

The present research work is based on secondary data sources. The secondary data was obtained mainly from Ahmednagar Census Handbook and the tahsil level governmental and non-governmental agencies etc. from 1991 to 2011. The collected SC community population was further analyzed by using MS Excel and SPSS software.

Maps prepared for express decadal spatio-temporal changes in population and district delimited into high, medium, and low population areas using Arc GIS 10.4 software. Lastly, based on findings, suggestions have been given to improve the socio-economic conditions of the SC community.

\section{Results And Discussions}

It has been observed that the SC population of Akole Sangamner, Newasa, Pathardi, Parner, and Jamkhed was below 15000 in the year 1971 and the population of Rahuri,
Shevgaon Shrigonda, and Karjat was between 15001 to 20000 while the population of Kopargaon was between 20001 to 25000 and Shrirampur and Nagar recorded the above 25000 population.

In 1981 Akole, Parner and Jamkhed indicated a population between 15000 whereas, Sangamner, Shevgaon, and Pathardi reported between 15001 to 20000 population. Shrigonda and Karjat's population was between 2001 to 25000. While tahasils like Kopargaon, Shrirampur, Rahuri, Newasa, Nagar, and Karjat showed above 25000 population.

Once again in 1991, Akole and Parner indicated below 15000 population and only Jamkhed was between 15001 to 20000. While the Shevgaon and Pathradi tahasil's population was between 20001 to 25000 and Sangamner, Kopargaon, Shrirampur Rahuri, Newasa, Nagar, Shrigonda, and Karjat recorded above 25000 population.
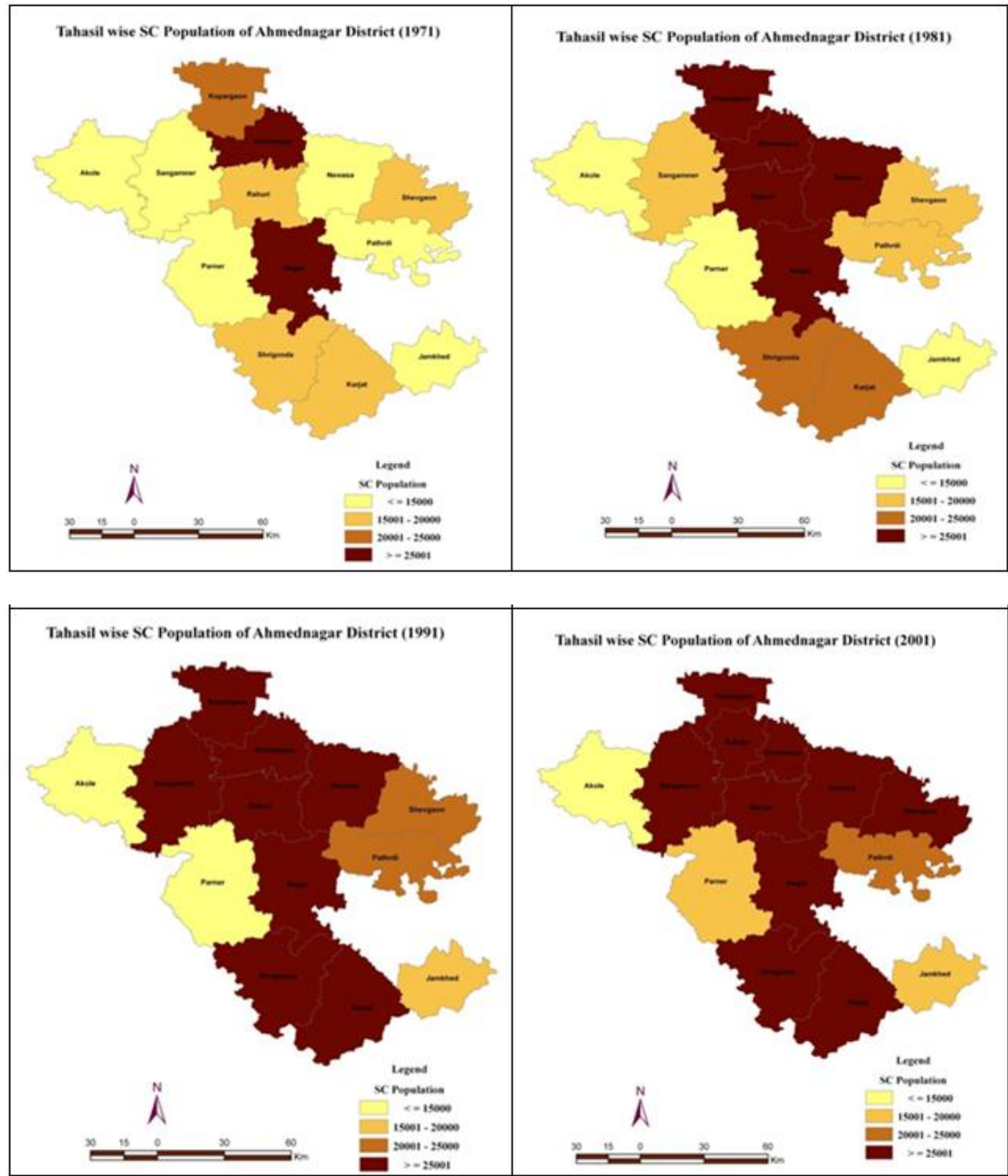

Figure 1: Population distribution of SC in Ahmednagar District

Volume 4 Issue 2, 2022 
Table 1: SC Population in Ahmednagar District 1971 to 2011.

\begin{tabular}{|c|c|c|c|l|}
\hline Years & Below 15000 & 15001 to 20000 & 20001 to 25000 & \multicolumn{1}{|c|}{ Above 25000 } \\
\hline 1971 & $\begin{array}{c}\text { Akole, Sangamner, Newasa, } \\
\text { Pathardi, Parner, Jamkhed }\end{array}$ & $\begin{array}{c}\text { Rahuri, Shevgaon, } \\
\text { Shrigonda, Karjat, }\end{array}$ & Kopargaon, & Shrirampur, Nagar, \\
\hline 1981 & Akole, Parner, Jamkhed & $\begin{array}{c}\text { Sangamner, Shevgaon, } \\
\text { Pathardi, }\end{array}$ & Shrigonda, Karjat, & $\begin{array}{l}\text { Kopargaon, Shrirampur, Rahuri, } \\
\text { Newasa, Nagar, Karjat }\end{array}$ \\
\hline 1991 & Akole, Parner & Jamkhed & Shevgaon, Pathardi & $\begin{array}{l}\text { Sangamner, Kopargaon, Shrirampur, } \\
\text { Rahuri, Newasa, Nagar, Shrigonda, } \\
\text { Karjat }\end{array}$ \\
\hline 2001 & Akole & Parner, Jamkhed & Pathardi & $\begin{array}{l}\text { Sangamner, Kopargaon, Shrirampur, } \\
\text { Rahuri, Newasa, Shevgaon, Nagar, } \\
\text { Shrigonda, Karjat, Rahata }\end{array}$ \\
\hline 2011 & Akole, & Parner & $\begin{array}{l}\text { Sangamner, Kopargaon, Shrirampur, } \\
\text { Rahuri, Newasa, Shevgaon, Pathardi, } \\
\text { Nagar, Shrigonda, Rahata }\end{array}$ \\
\hline
\end{tabular}

(Source: Computed by Researcher)

In the year 2001, the SC population of Akole was below 15000. Parner and Jamkhed werebetween 15001 to 20000. The Pathardi was between 20001 to 25000 . SC population of Sangamner, Kopargaon, Shrirampur, Rahuri, Newasa, Shevgaon, Nagar, Shrigonda, Karjat, and Rahata was above 25000. The SC population of Akole was below 15000 and only Parner has been recorded population between 15001 to 20000. The Jamkhed's population was between 20001 to 25000. SC population of Sangamner, Kopargaon, Shrirampur, Rahuri, Newasa, Shevgaon, Nagar, Shrigonda, Karjat, and Rahata was recorded above 25000 in the year 2011 ,

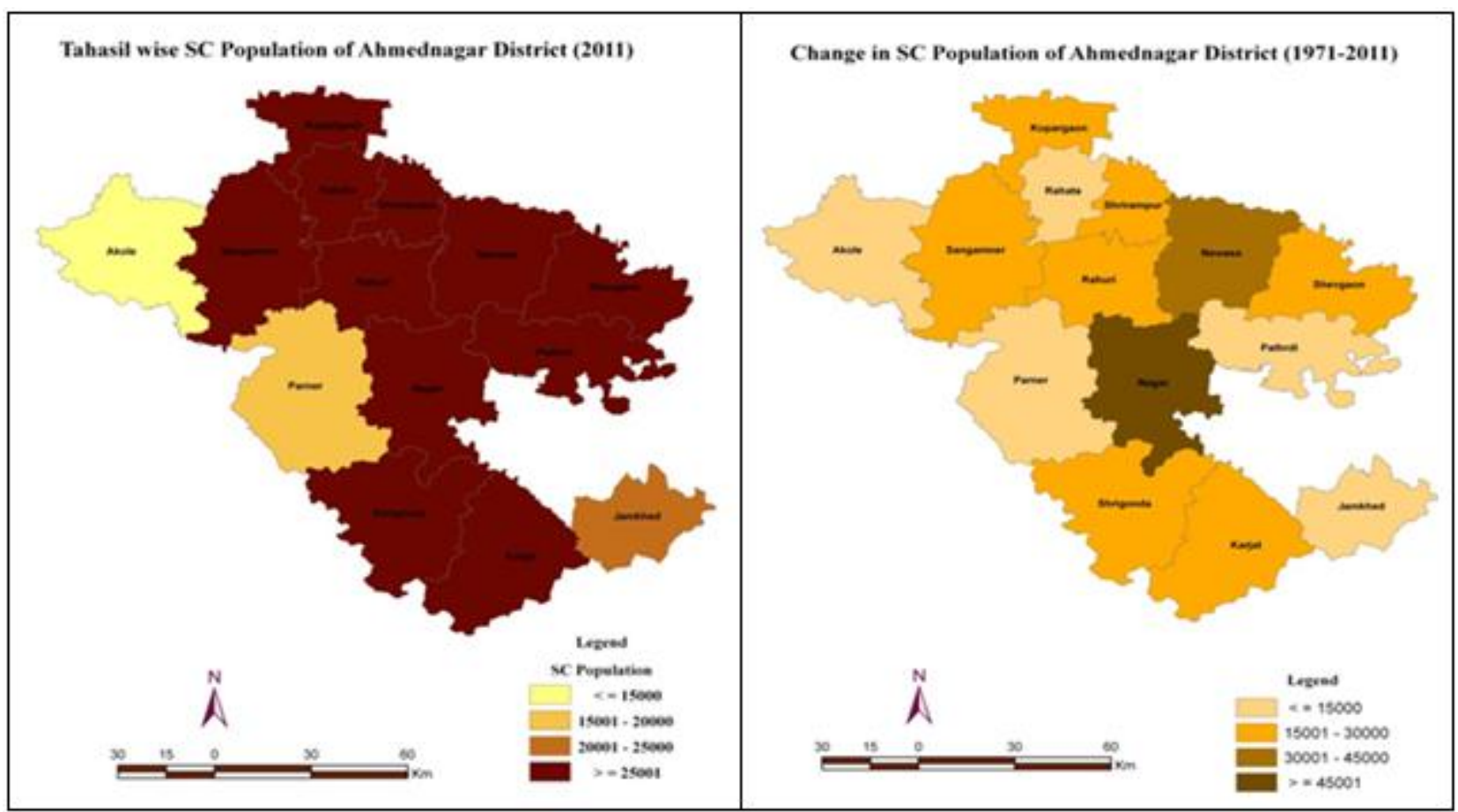

Figure 2: Change in population of SC in Ahmednagar district during 1971 to 2011

The spatio-temporal change in the SC population has been investigated from 1971 to 2011, during this period Nagar tahsil is shown below 15000 population while Nawasa tahsil indicates the change between 15000 to 30000 . These two tahsils recorded fewer variations in the SC population Whereas, seven tahasils i. e. Sangamner, Kopargaon, Shrirampur Rahuri, Shevgaon Shrigonda, and Karjat have been recorded change between 30000 to 45000. While Akole, Pathardi, Parner, Jamkhed, and Rahata tahsils have been indicated above 45000 population.

\section{Conclusion}

The present study focus on the spatio-temporal change of SC population distribution in Ahmednagar district. For that
Census data was used to obtain the spatio-temporal population, an attempt has been made to investigate the SC population from 1971 to 2011 . It is concluded from the present research that Nagar tahsil with urban characteristics is showing less variation in SC population (below 15000) followed by Newasa (between 15000 to 30000) as compared with other tahsils. On other hand, Sangamner, Kopargaon, Shrirampur Rahuri, Shevgaon Shrigonda, and Karjat tahsils have been recorded the population change between 30000 to 45000 and in the reaming five tahsils, Akole, Pathardi, Parner, Jamkhed, and Rahata indicated the greater change in SC population (above 45000). 


\section{References}

[1] Acharya M. M. (1993): 'Geographical Analysis of Scheduled Caste Population in Marathawada and Western Maharashtra', Unpublished Ph. D. Thesis, Shivaji University Kolhapur.

[2] Asha Bhende and Tara Kanitkar (2011): Population Studies, Himalaya publishing house, Bombay. Pp.139154

[3] Chandna, R. C. (1986): Geography of Population Concept, Determinants and Patterns, Kalyani Publishers, New Delhi, p.100, 188

[4] Ghosh B. N., (1985): Fundamentals of population geography, Sterling Pub: New Delhi

[5] Government of Maharashtra, (1961 to 2011): "Socioeconomic Abstract, Ahmednagar District"

[6] Government of India (2001): "Total Population, Population of Scheduled Castes and Scheduled Tribes and Their Proportions to the Total Population", Office of the Registrar General and Census Commissioner, New Delhi.

[7] Harwalkar, D. S. (2010): "A Study of Population Characteristics in Solapur District", Unpublished M. Phil. Dissertation, Tilak Maharashtra Vidyapeeth, Pune.

[8] K. Sita (1986): 'Spatial Pattern of Scheduled Caste Tribes in Maharashtra', The Geographer, vol.37, Pp 5359.

[9] Pacharne S. R, 2012. 'The Study Population Growth in Ahmadnagar District'. International Journal of Natural and Applied Science. Vol-1 (1) Pp-01-05.

[10] Ramotra K. C. (1988): 'Scheduled Caste Literacy in North-Western India: A Spatial Perspective', National Geographer, Vol. XXIII, No.2 Pp.147-155.

[11] Singh Deva, (2006): 'A study of Demographic Aspects of Scheduled casts and scheduled Tribes in Manipur'. Deccan Geographer. Vol-41 No.02, Pp-91-98

[12] Singh Dharm (2005): 'Geographical Analysis of Scheduled Caste in Utter Pradesh', Unpublished Ph. D. Thesis in Jamia Millia Islamia University

[13] Tripathi Rajmani (1999): 'Socio-Economic Profile of Scheduled Caste Population in India', Geographical Review of India, Vol.61, No.2, Pp.47-59.

[14] Tiwari, R. K. (2000): "Special Analysis of Scheduled caste Population in the Jharkhand Area ", Geographical Review of India, Kolkata, Vol.61, No.4, Pp.380-389 